\title{
VARIASI KOMPOSISI PAKAN BUATAN UNTUK SERANGGA: SUATU KAJIAN PUSTAKA
}

\section{VARIATION OF ARTIFICIAL DIET COMPOSITION FOR INSECT: A LITERATURE REVIEW}

\author{
I GEDE KETUT SUSRAMA \\ Program Studi Agroekoteknologi, Fakultas Pertanian, Universitas Udayana \\ Jl. P.B. Sudirman, Denpasar 80232 Bali \\ Email: ketutsusrama@unud.ac.id
}

Diterima 9 Januari 2018 Disetujui 16 Oktober 2018

\section{INTISARI}

Pakan buatan untuk memperbanyak serangga sangat diperlukan apabila memerlukan serangga dalam jumlah banyak secara berkala dan atau berlanjut misalnya untuk penelitian efikasi pestisida, upaya konservasi atau untuk kegiatan pengendalian lalat buah dengan teknik jantan mandul dimana diperlukan jutaan lalat jantan setiap minggunya untuk disterilkan dan selanjutnya dilepas secara bertahap. Pakan buatan juga akan meningkatkan efisiensi waktu, energi dan dana dalam pengadaan serangga yang dibutuhkan dibandingkan dengan pengadaan serangga dengan pakan alaminya. Berbagai klasifikasi pakan buatan dan komposisinya telah dikembangkan selama ini dengan berbagai tingkat keberhasilan.

\section{Kata kunci: efisiensi, memperbanyak serangga, pakan buatan}

\section{ABSTRACT}

Artificial diet for insect rearing is necessary at the time a lot of insects required periodically and continuously such as for pesticide efficacy research, biodiversity conservation, and for the activity of fruit fly management with the sterile male technique for instance where it needs millions fruit flies weekly to be sterilized and then subsequently released. Insect artificial diet will also increase the efficiency of time, energy and fund in the procurement of insects compared to insect rearing with its natural diet. Various artificial diet classifications and its compositions have been developed so far in varying degrees of rearing success.

\section{Keywords: artificial diet, efficiency, insect rearing}

\section{PENDAHULUAN}

Arlene McMorran adalah seorang ilmuwan Kanada yang pertama kali pada tahun 1965 terpikir membuat pakan buatan untuk memperbanyak serangga. Komposisi pakan buatan yang dibuat oleh Arlene McMorran tersebut, sudah dicoba dan berhasil dipakai untuk memperbanyak 103 spesies Lepidoptera (Hervet et al., 2016). Pembuatan pakan buatan untuk serangga, awalnya diinisiasi oleh kondisi empat musim di negaranegara dengan iklim sedang dimana tidak mungkin menyediakan sayur seperti kubis sepanjang tahun misalnya pada puncak musim dingin antara bulan Desember dan bulan Januari untuk pakan alami Plutella atau Crocidolomia. Ada juga masalah penyimpanan bahan alami yang cenderung cepat rusak, layu, busuk atau kering sehingga tidak bisa lagi dipakai pakan alami untuk serangga. Berangkat dari berbagai kendala yang muncul bila memperbanyak serangga dengan pakan alaminya kemudian dikembangkan perbanyakan serangga dengan pakan buatan. Memperbanyak serangga dengan pakan alami, berdasarkan pada pengalaman penulis memperbanyak serangga, kemungkinan akan menemui berbagai kendala seperti: 1) pakan alami tersebut sering tidak tersedia sepanjang waktu atau pada waktu tertentu tersedia berlebihan akan tetapi pada waktu lain sulit ditemukan karena memang ada jenis produk tanaman yang tersedianya musiman, 2) pakan alami tersebut menyebabkan wadah tempat pemeliharaan berbau menyengat, 3) sisa pakan alami yang tersisa dalam wadah menyebabkan kontaminasi mikroba, 4) lokasi tempat pakan alami tersebut tersedia jauh dan atau sulit dijangkau kendaraan, 5) pakan alami tersebut tidak tahan simpan, 6) harus diberikan atau diganti setiap hari, dan 7) bisa menjadi sumber infeksi patogen bagi serangga yang dipelihara. Pakan buatan mempunyai kelebihan sebagai berikut: 1) pakan buatan bisa dibuat pada saat bahan baku tersedia berlimpah kemudian bisa disimpan dalam kurun waktu relatif lama dengan bantuan preservatif dan sarana pendingin, freezer atau kulkas, 2) Perbanyakan serangga dengan pakan buatan bisa dilakukan dalam jangka waktu lama dan sepanjang tahun, 3) serangga hasil perbanyakan lebih seragam karena pakan yang diberikan dari waktu ke waktu kuantitas dan kualitasnya relatif sama, 4) pengerjaan lebih efisien baik waktu maupun tenaga, 5) pakan buatan bisa dibuat lebih higinis dan kandungan nutrisinya lebih bisa dikendalikan dibanding pakan alami, 6) 
memungkinkan memperbanyak serangga dalam jumlah besar dalam waktu singkat, dan 7) bisa untuk mendukung pengembangan ilmu nutrisi pakan buatan untuk serangga. Hervet et. al.(2016) selanjutnya menyatakan bahwa umumnya perbanyakan serangga herbivora bertujuan untuk menurunkan kebutuhan tenaga kerja, waktu, ruang dan biaya menumbuhkembangkan tanaman alaminya.

Memang tidak semua serangga bisa cocok dikembangbiakan dengan pakan buatan atau tidak harus dengan pakan buatan karena ada serangga seperti ulat buah jagung Helicoverpa armigera misalnya, bisa diperbanyak baik dengan pakan alaminya maupun dengan pakan buatan (Amer and ElSayed, 2014). Untuk itu perlu penelusuran literatur terlebih dahulu sebelum memutuskan memperbanyak serangga dengan pakan buatan untuk memastikan bahwa sudah ada yang mencoba sebelumnya dan berhasil memperbanyak serangga yang akan diperbanyak dengan pakan buatan. Apabila acuan literatur belum ada maka perlu dicoba dulu dengan pakan alami dan dibandingkan dengan beberapa komposisi pakan buatan untuk membandingkan parameter tumbuhkembangnya. Pada prinsipnya serangga bisa diperbanyak dengan pakan buatan hanya saja apabila ada ketidakcocokan antara serangga yang diperbanyak dan pakan buatannya maka tumbuhkembangnya kemungkinan tidak sebaik apabila diperbanyak dengan pakan alaminya. Noda and Kamano (2002) melaporkan keberhasilan memperbanyak kepik hijau Nezara viridula dengan pakan buatan meredik semi padat. Tetapi kemudian Fortes et al. (2006) menyatakan bahwa ternyata dibanding apabila diperbanyak dengan pakan buatan, parameter tumbuhkembang seperti viabilitas telur, viabilitas larva dan masa hidup kepik hijau $N$. viridula tidak sebaik kalau diperbanyak dengan pakan alaminya. Berbagai kondisi tentunya mempengaruhi keberhasilan pemeliharaan, oleh karena itu setelah melakukan penelusuran literatur membuat pengalaman mengerjakan menjadi sangat penting.

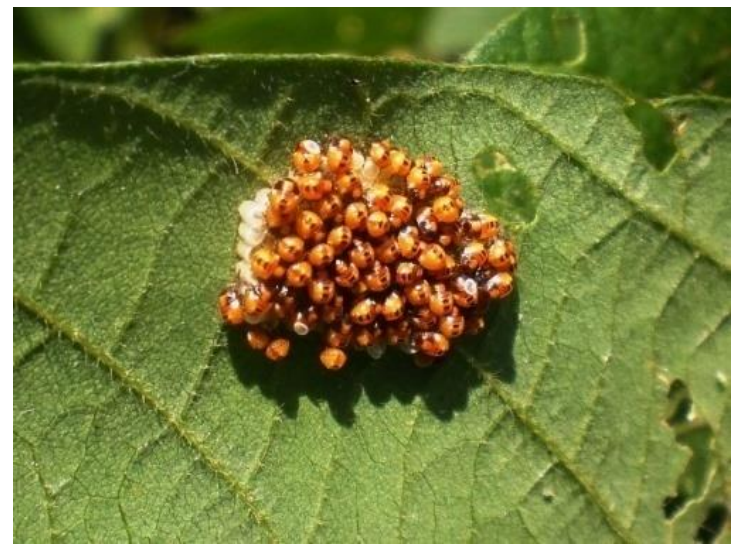

Gambar 1. Kepik hijau instar awal pada pakan alaminya daun kedelai (Foto: Koleksi pribadi)

Akan tetapi cukup banyak juga serangga yang lebih baik diperbanyak dengan pakan buatan, seperti dinyatakan oleh Abdullah et al. (2000) bahwasanya ulat tentara Spodoptera exigua lebih baik diperbanyak dengan pakan buatan dibandingkan apabila diperbanyak dengan salah satu pakan alaminya yaitu daun kedelai.

\section{Pakan Buatan Untuk Serangga Berbasis Agar}

Tekstur pakan buatan dan juga sifat fisik pakan buatan lainnya kemungkinan akan mempengaruhi penerimaan dan palatabilitas serangga yang dipelihara. Sudah dipahami bahwa serangga, sesuai dengan tipe mulutnya secara umum dianggap cocok dengan pakan padat tetapi mempunyai kandungan air tinggi seperti kharakteristik fisik yang umum dari bahan tanaman.

\section{Pakan Buatan Berbasis Agar yang Dicoba untuk Kupu-kupu Semak Coklat Satyrinae, Bicyclus spp.}

Penelitian pakan buatan ini merupakan penelitian pakan yang tidak begitu berhasil. Hasil perbanyakan dengan pakan alami berupa tanaman jagung lebih baik dibandingkan dengan hasil pemberian pakan buatan. Disamping itu perkembangan sayap ternyata juga kurang bagus, walaupun ke dalam komposisi pakan sudah ditambahkan minyak rami (Holloway et al., 1991). Mengingat pentingnya peranan minyak rami bagi perkembangan sayap kupu-kupu, kemungkinan meningkatkan konsentrasinya sebagai bagian dalam membuat komposisi modifikasi dari komposisi Holloway et al. (1991) ini, sangat menarik. Pentingnya peranan minyak rami sebagai komponen dalam komposisi pakan buatan untuk Lepidoptera juga dilaporkan oleh Ngatimin et al. (2014) yang menyatakan bahwa apabila komposisi pakan buatan kupu-kupu dibuat tanpa minyak rami akan menyebabkan kelumpuhan pada serangga dewasa pada saat perkembangan sayap.

Kemungkinan komposisi pakan masih kurang sesuai atau kurang lengkap bagi kebutuhan nutrisi untuk ordo Lepidoptera genus Bicyclus. Bicyclus banyak dipakai penelitian serangga di negara lain bukan di Indonesia. Untuk penelitian berbagai aspek serangga, kita perlu memakai kupu-kupu dengan ukuran relatif kecil $(4 \mathrm{~cm})$ seperti Bicyclus. Memerlukan wadah pemeliharaan yang tidak besar dan perkembangbiakannya cepat. Apabila suatu saat nanti perlu melakukan perbanyakan kupu-kupu yang mirip dengan keberadaan Bicyclus dengan pakan buatan berarti perlu 
melakukan modifikasi komposisi pakan buatan dari komposisi pakan buatan Bicyclus yang sudah dicoba pada penelitian ini. Komposisi yang dipakai dalam penelitian Holloway et al. (1991) itu tertera pada Tabel 1.

Kegagalan perbanyakan Bicyclus tersebut diatas salah satunya kemungkinannya disebabkan oleh kekurangan fagostimulan. Untuk membuat pilihan fagostimulan yang tepat untuk serangga tertentu diperlukan penelusuran pustaka dan atau penelitian eksperimental. Cara yang lebih cepat dan murah adalah dengan menambahkan gerusan atau ekstrak pakan alaminya (Susrama, 2017) dengan pertimbangan bahwa pakan alami serangga tertentu pasti mengandung fagostimulan yang spesifik bagi serangga bersangkutan. Pendapat itu didukung hasil penelitian Wang et al. (2013) yang menyatakan bahwa pakan buatan terbaik untuk penggerek polong kacang Maruca vitrata Fabricius adalah pakan buatan semi sintetis dengan campuran tepung kacang tunggak, pakan alami serangga hama tersebut. Kemungkinan lain adalah seperti dinyatakan oleh Russell and Pelz-Stelinski (2015) bahwa kegagalan perbanyakan serangga bisa terjadi akibat tidak tersedianya asam amino esensial dalam pakan buatan yang diberikan yang sangat diperlukan dalam perkembangan larva dari satu instar ke instar berikutnya.

Tabel 1. Komposisi Pakan Buatan Berbasis Agar untuk Bicyclus spp.

\begin{tabular}{lc}
\hline Komposisi & Kuantitas \\
\hline Tepung kacang putih & $75 \mathrm{~g}$ \\
Yeast & $17.5 \mathrm{~g}$ \\
Asam Askorbat & $3.5 \mathrm{~g}$ \\
Kolesterol & $0.5 \mathrm{~g}$ \\
Asam Sorbat & $0.5 \mathrm{~g}$ atau o.2g \\
Metal para hidroksi benzoat & $0.5 \mathrm{~g}$ atau 0.2g \\
Streptomisin & $0.4 \mathrm{~g}$ atau 0.1g \\
Tokoferol 10\% dalam minyak germ & $3 \mathrm{ml}$ \\
Minyak rami & $4 \mathrm{ml}$ \\
Agar & $15 \mathrm{~g}$ \\
Air deionized & $400 \mathrm{ml}$ \\
\hline
\end{tabular}

Sumber: Holloway et al. (1991)

\section{Pakan Buatan untuk Serangga Berbasis Agar yang Disempurnakan untuk Ulat Grayak Spodoptera litura}

Gupta et al. (2005) memperkenalkan komposisi pakan buatan untuk serangga berbasis agar dengan tambahan kandungan bahan dalam komposisinya relatif agak banyak tetapi mengingat $S$. litura merupakan hama yang sangat penting pada berbagai jenis tanaman, wajar kalau diberikan perhatian khusus yakni dilakukan perbanyakan dengan diberikan pakan buatan dengan kualitas pakan buatan yang lebih baik. Pakan ini sudah dipublikasikan sangat sukses untuk memperbanyak $S$. litura. Kandungan dan kuantitas komponen dalam komposisi pakan untuk $S$. litura buatan Gupta et al. (2005) tertera selengkapnya dalam Tabel 2.

Tabel 2. Komposisi Pakan Buatan Berbasis Agar untuk S. litura

\begin{tabular}{lc}
\hline Kandungan & Kuantitas \\
\hline Germ gandum & $26 \mathrm{~g}$ \\
Kacang azuki & $51,3 \mathrm{~g}$ \\
Kacang arab & $56 \mathrm{~g}$ \\
Yeast & $31,6 \mathrm{~g}$ \\
Kasein & $15,2 \mathrm{~g}$ \\
Asam askorbat & $3,2 \mathrm{~g}$ \\
Kolesterol & $0,5 \mathrm{~g}$ \\
Multivitamin multimineral & $2 \mathrm{kapsul}$ \\
Vitamin E & $1 \mathrm{kapsul}$ \\
Minyak kastor & $1 \mathrm{ml}$ \\
ABDEC drop & $2 \mathrm{ml}$ \\
Metal p-hidroksi benzoat & $1,8 \mathrm{~g}$ \\
Asam sorbat & $1,3 \mathrm{~g}$ \\
Streptomisin & $0,25 \mathrm{~g}$ \\
Larutan formaldehid & $2 \mathrm{ml}$ \\
Agar & $16,4 \mathrm{~g}$ \\
Akuades & $820 \mathrm{ml}$ \\
\hline
\end{tabular}

Sumber: Gupta et al. (2005) 
Divakara and Manjulakumari (2015) membahas tentang kelebihan rearing dengan pakan buatan adalah bisa mengatasi masalah kanibalisme larva $S$. litura. Perbanyakan serangga dengan pakan buatan memungkinkan pemeliharaan dilakukan dalam wadah yang kecil sehingga larva bisa dipelihara satu larva dalam satu wadah, dengan demikian kanibalisme tidak terjadi. Untuk efisiensi penggunaan agar, Gillespie (1993) menyarankan menurunkan rasio agar-serat sampai batas tertentu sepanjang tidak mempengaruhi parameter tumbuhkembang serangga yang dipelihara dan juga menyarankan penggunaan pektin sebagai pengganti agar, apabila agar sulit didapat atau harganya terlalu mahal.
Pakan Buatan untuk Serangga Berbasis Agar Semi Sintetis untuk Ulat Daun Kapas Spodoptera littoralis

Pakan buatan untuk S. littolaris ini merupakan hasil penelitian Sorour et al. (2011) yang dianggap ekonomis karena kandungan komposisinya relatif sedikit yaitu hanya dibuat dari 7 jenis bahan saja. Pakan buatan ini boleh dikatakan sangat disederhanakan yang mana hanya mengandung bahan-bahan yang harus ada saja dalam membuat suatu pakan buatan untuk serangga dan sangat menarik untuk dicoba. Selengkapnya bahan yang dipakai untuk membuat pakan buatan tersebut tertera pada Tabel 3 .

Tabel 3. Komposisi Pakan Buatan Berbasis Agar untuk S. littoralis

\begin{tabular}{lccc}
\hline Kandungan & Pakan standar & Pakan A & Pakan B \\
\hline Agar (g) & 60 & 20 & 30 \\
Tepung (g) & 0 & 150 & 150 \\
Yeast (g) & 150 & 150 & 150 \\
Asam askorbat (g) & 15 & 15 & 15 \\
Metil p-hidroksi benzoat (g) & 9.5 & 9.5 & 9.5 \\
Asam sorbat (g) & 5 & 5 & 5 \\
Formaldehid 40\% (ml) & 10 & 10 & 10 \\
Akuades (ml) & 2000 & 2000 & 2000 \\
\hline \multicolumn{4}{c}{ Sumber: Sorour et al. (2011) }
\end{tabular}

Pakan Buatan Serangga Berbasis Agar Semi Sintetis untuk Ngengat Punggung Berlian Plutella xylostella

Hama ngengat punggung berlian berupakan hama tanaman utama atau hama yang sangat sering menyerang tanaman kubis-kubisan dan menyebabkan kerugian ekonomi yang signifikan hampir di seluruh dunia termasuk di Bali. Studi komparatif antara upaya memperbanyak $P$. xylostella dengan pakan buatan berbasis kacang kedelai dengan salah satu pakan alaminya yaitu bibit mustard menunjukkan hasil perbanyakan dimana pakan buatan memberikan tumbuhkembang $P$. xylostella lebih baik dibandingkan diperbanyak dengan pakan alaminya, bibit mustard (Murthy et al., 2005). Hasil penelitian tersebut menunjukkan untuk memperbanyak $P$. xylostella lebih baik dilakukan dengan memberikan pakan buatan, lebih efisien dan lebih mudah. Htwe et al. (2009) juga melakukan penelitian pakan buatan untuk ngengat punggung berlian dan membuat kesimpulan yang senada dengan Murthy et al. (2005), bahwa dibandingkan dengan strain liar, strain hasil perbanyakan dengan pakan buatan menghasilkan tingkat bertahan hidup lebih tinggi, pupa lebih berat dan masa tumbuhkembang lebih pendek. memperbanyak $P$. xylostella yang sudah dicoba oleh Murthy et al. (2005) adalah seperti tertera pada Tabel 4. Komposisi pakan buatan semi sintetis untuk

Tabel 4. Komposisi Pakan Buatan Berbasis Agar Semi Sintetis untuk P. xylostella

\begin{tabular}{lc}
\hline Komponen & Kuantitas \\
\hline Tepung daun kubis & $15 \mathrm{~g}$ \\
Germ gandum & $15 \mathrm{~g}$ \\
Yeast & $8 \mathrm{~g}$ \\
Sukrosa & $135 \mathrm{~g}$ \\
Vitamin premix & $5 \mathrm{~g}$ \\
Asam askorbat & $2 \mathrm{~g}$ \\
Inositol & $0,09 \mathrm{~g}$ \\
Kolin klorida & $6,5 \mathrm{~g}$ \\
Kasein & $21 \mathrm{~g}$ \\
Garam Wessons & $5 \mathrm{~g}$ \\
Aureomicin & $0,8 \mathrm{~g}$ \\
Asam sorbat & $0,4 \mathrm{~g}$ \\
Metal para-hidroksi benzoat & $0,77 \mathrm{~g}$ \\
Kolesterol & $1,5 \mathrm{~g}$ \\
Larutan KOH & $2,5 \mathrm{ml}$ \\
Formalin 40\% & $3 \mathrm{ml}$ \\
Agar & $15 \mathrm{~g}$ \\
Air & $2000 \mathrm{ml}$ \\
\hline \multicolumn{2}{c}{ Sumber: Murthy et al. (2005) }
\end{tabular}


Perera et al. (2015) menyimpulkan berdasarkan pada hasil penelitiannya bahwa beberapa bahan baku yang relatif berharga mahal untuk komposisi pembuatan pakan buatan untuk ngengat punggung berlian bisa diganti, seperti aureomisin dengan tetrasiklin dan sebagian dari agar bisa diganti dengan gelatin. Hou and Hsiao (1986) menambahkan asam linolenat dan asam linoleat ke dalam komposisi pakan buatannya dan menyatakan bahwa apabila kedua jenis asam itu sudah ada dalam pakan, penambahan alpha Tocoferol tidak menyebabkan peningkatan tumbuhkembang yang signikan pada ngengat punggung berlian. Dalam komposisi pakan diatas, kasein ditambahkan sebagai sumber protein bagi serangga yang diperbanyak dengan konsentrasi relatif tinggi. Menurut Salvador et al. (2010) penambahan kasein ke dalam komposisi pakan untuk serangga perlu mendapat perhatian khusus mengingat kandungan kasein tinggi bisa menimbulkan pengaruh alelokimia.

\section{Pakan Buatan Serangga Berbasis Tepung Tapioka}

Umumnya pakan buatan untuk serangga berbasis agar atau mengandung agar dan persentase kandungannya tinggi serta agar termasuk produk yang berharga relatif mahal. Penggunaan tapioka sebagai bahan utama dalam komposisi pakan serangga akan menurunkan biaya perbanyakan serangga. Abbasi et al. (2007) mengembangkan pakan buatan berbasis tepung tapioka tanpa agar sama sekali. Dalam penelitiannya dibandingkan perbanyakan ulat buah jagung $H$. armigera dengan pakan buatan berbasis agar dan pakan buatan berbasis tapioka. Hasilnya vigor dan viabilitas serangga tidak berbeda nyata. Mengingat harga agar sangat mahal dan lebih sulit didapat dibandingkan dengan tepung tapioka maka penemuan pakan buatan serangga berbasis tapioka patut disyukuri. Tabel 5 dibawah ini merupakan bahan yang dipakai Abbasi et al. (2007) dalam membuat pakan buatan serangga berbasis tepung tapioka.

Tabel 5. Komposisi Pakan Buatan Serangga Berbasis Tepung Tapioka

\begin{tabular}{|c|c|c|c|c|c|c|}
\hline \multirow{2}{*}{ Komponen } & \multicolumn{2}{|l|}{ Berat (g) } & \multirow{2}{*}{ Pakan tapioka (\%) } & \multirow{2}{*}{ Pakan agar (\%) } & \multicolumn{2}{|l|}{ Larutan Stok Vitamin } \\
\hline & Tapioka & Agar & & & Kandungan & Kuantitas \\
\hline Agar & 0 & 7.1 & $\mathrm{O}$ & 3.6 & Kalsium pantotanat & $9.6 \mathrm{~g}$ \\
\hline Tepung Tapioka & 60 & 0 & 24 & 0 & Asam nikotin amida & $4.8 \mathrm{~g}$ \\
\hline Tepung kacang & 171.4 & 171.4 & 70 & 89 & Riboflavin & $2.4 \mathrm{~g}$ \\
\hline Asam askorbat & 2 & 2 & 0.8 & 1 & Asam folat & $2.4 \mathrm{~g}$ \\
\hline Asam sorbat & 0.86 & 0.86 & 0.3 & 0.5 & Timin hidroklorida & $1.2 \mathrm{~g}$ \\
\hline Yeast & $5 \cdot 7$ & $5 \cdot 7$ & 2.3 & 3 & Piridoksin hidroklorida & $1.2 \mathrm{~g}$ \\
\hline $\begin{array}{l}\text { Metal-para } \\
\text { hidroksi benzoat }\end{array}$ & 2.9 & 2.9 & 1.2 & 1.5 & Biotin & $0.096 \mathrm{~g}$ \\
\hline Campuran vitamin & 1.42 & 1.42 & 0.6 & 0.7 & Vitamin B1 & $0.0048 \mathrm{~g}$ \\
\hline Formaldehid & 1.7 & 1.7 & 0.6 & 0.7 & Akuades steril & 40oml \\
\hline Total & 245.98 & 193.08 & 99.8 & 100 & & \\
\hline
\end{tabular}

Pakan buatan untuk serangga berbasis tepung tapioka juga dikembangkan untuk memperbanyak $S$. litura seperti yang sudah dilakukan oleh Sujatha and Joseph (2011). Menurut Sujatha and Joseph (2011), biaya yang diperlukan untuk memproduksi satu pupa $S$. litura dengan pakan buatan berbasis agar 1,24 rupee sedangkan dengan pakan buatan berbasis tapioka hanya 0,9 rupee. Akan tetapi, Blanco et al. (2009) mengingatkan bahwa kandungan protein pakan buatan untuk serangga bersumber dari kacang kedelai atau ekstrak embrio gandum sangat penting yaitu 2,51\% yakni berpengaruh nyata pada tumbuhkembang serangga yang diperbanyaknya. Untuk mempertimbangkan dalam membuat pilihan tepung kacang, hasil penelitian Hamed and Nadeem (2008) bisa dipertimbangkan bahwa kacang arab tidak kalah baik untuk dipakai sebagai sumber protein dalam komposisi pakan untuk $H$. Armigera.

\section{Pakan Buatan Serangga Berbasis Kacang-Beras}

Alfazairy et al. (2012) mengklaim bisa membuat pakan buatan serangga tanpa agar untuk pertama kali. Tetapi seperti tertulis dalam hasil penelusuran ini ada peneliti yang lebih dulu membuat pakan buatan untuk serangga tanpa kandungan agar tetapi dengan berbasis pada tepung tapioka yaitu Abbasi et al. (2007). Walaupun demikian, kemungkinan Alfazairy et al. (2012) adalah ahli pakan buatan serangga yang pertama membuat pakan buatan non-agar dengan bahan utama kombinasi kacang dan beras. Pada Tabel 6 tertera komposisi pakan buatan serangga non agar berbasis kacang dan beras hasil penelitian Alfazairy et al. (2012) dan berhasil memperbanyak ulat daun kapas $S$. littoralis dengan sukses. 
Tabel 6. Komposisi Pakan Buatan Serangga Berbasis Kacang dan Beras

\begin{tabular}{lc}
\hline Komponen & Kuantitas \\
\hline Kacang lentil kuning & $180 \mathrm{~g}$ \\
Beras & $25 \mathrm{~g}$ \\
Yeast & $18,5 \mathrm{~g}$ \\
Asam askorbat & $3 \mathrm{~g}$ \\
Asam sorbat & $4 \mathrm{~g}$ \\
Natrium benzoat & $2,5 \mathrm{~g}$ \\
Formalin 37-49\% & $1 \mathrm{ml}$ \\
Air keran & $575 \mathrm{ml}$ \\
\hline \multicolumn{2}{c}{ Sumber: Alfazairy et al. (2012) }
\end{tabular}

\section{Pakan Buatan Berbasis Pakan Buatan Komersial}

Genc and Nation (2004) melakukan modifikasi pada pakan buatan untuk serangga formula PB (Pinto Bean) yang sudah dipasarkan dengan cara menambahkan $10 \%$ daun tanaman inang yang sudah dikeringbekukan ("freeze dried") dengan maksud untuk meningkatkan kualitas pakan buatan tersebut. Penambahan tanaman inang kering yang sudah dikeringbekukan menurut Genz and Nation (2004) dapat meningkatkan tingkat oviposisi pada kupukupu bulan sabit, Phyciodes phaon.

\section{KEPUSTAKAAN}

Abbasi Haider Bilal, Khalique Ahmed, Feeroza Khalique, Najma Ayub, Hai Jun Liu, Syed Asad Raza Kazmi and Muhammad Nauman Aftab. 2007. Rearing the Cotton Bollworm, Helicoverpa armigera on a Tapioca-based Artificial Diet. J. Insect. Sci. 7: 1-7.

Abdullah Md., O. Sarnthoy and S. Chaeychomsri. 2000. Comparative Study of Artificial Diet and Soybean Leaves on Growth, Development and Fecundity of Beet Armyworm, Spodoptera exigua Hubner (Lepidoptera: Noctuidae). Kasetsart J. (Nat. Sci.). 34: 339-334.

Alfazairy A.A., H.A. Sadek, G.Z. Guirguis and H.H. Karam. 2012. An Agar-free Artificial Diet: A New Approach for the Low Cost Rearing of the Egyptian Cotton Leaf Worm, Spodoptera littoralis (Boisd.) (Lepidoptera: Noctuidae). J. Agric. Sci. res. 2(12): 639-647.

Amer A.E.A. and A.A.A. El-Sayed. 2014. Effect of different host plants and artificial diet on Helicoverpa armigera Hubner (Lepidoptera: Noctuidae) development and growth index. J. Entomol. 11(5): 299-305.

Blanco A. C., M. Portilla, C. A. Abel, H. Winters, R. Ford and D. Streett. 2009. Soybean flour and wheat germ proportions in artificial diet and their effect on the growth rates of tobacco budworm Heliothis virescens. J. Insect Sci. 9: 1-9.

Divakara Y. G. and D. Manjulakumari. 2015. Artificial diet formulation and its efficacy evaluation on development and reproduction of Spodoptera litura F., a polypahgous pest. Indian J. App. Res. 5(6): 55-57.

Fortes, P., S. R. Margo, A. R. Panizzi and J. R. P. Parra. 2006. Development of a Dry Artificial Diet for
Nezara viridula L. and Euschistus heros Fabricius (Heteroptera: Pentatomidae). Neotropical Ent. 35(5): 567-572.

Genc, H. and J. L. Nation. 2004. An Artificial Diet for the Butterfly Phyciodes phaon (Lepidoptera: Nymphalidae). Florida Entomologist 87(2): 194198.

Gillespie, D. Y. 1993. Development of mass-rearing methods for the sugarcane borer Eldana Sccharina (Lepidoptera: Pyralidae) II: Diet gelling agents. Proceedings of the South African sugar technologist'association. pp.127-129.

Gupta G. P., S. Rani, A. Birah and M. Raghuraman. 2005. Improved Artificial Diet for Mass Rearing of the Tobacco Caterpillar, Spodoptera litura (Lepidoptera: Noctuidae). Intern. J. Trop. Insect Sci. 25(1): 55-58.

Hamed, M. and S. Nadeem. 2008. Rearing of Helicoverpa armigera (Hub.) on artificial diets in laboratoty. Pakistan J. Zool. 40(6): 447-450.

Hervet V. A. D., R. A. Laird and K. D. Floate. 2016. A Review of the McMorran Diet for Rearing Lepidoptera Species with Addition of a Further 39 Species. J. Insect Sci. 16(1): 1-7.

Holloway G. J., P. M. Brakefield, S. Kopman and J. J. Windig. 1991. An Artificial Diet for Butterflies, Including Bicyclus Species, and Its Effect on Development Period, Weight, Wing Pattern. J. Res. Lepidop. 30(1-2): 121-128.

Hou, F. R. and M. L. Hsiao. 1986. An improved diet for rearing the diamondback moth Plutella xylostella and its requirement for fatty acids. Chinese $J$. Entomol. 6: 31-37.

Htwe, A. N., Keiji Takasu and Masami Takagi. 2009. Laboratory rearing of the Diamondback moth Plutella xylostella (L.) (Lepidoptera: Plutellidae) with artificial diet. J. Fac. Agr. Kyushu Univ., 53(1): 147-151.

Murthy K. S., T. Venkatesan and S.K. Jalali. 2005. Development of Plutella xylostella (L.) on Semisynthetic Diets Suitability of Diet Reared Host to Larval Parasitoid Cotesia plutellae (Kurdyumof). Ann. Pl. Protec. Sci. 13(2): 355-358.

Ngatimin, A. S. Nur, A. P. Saranga, N. Agus, A. Ahmad and I. Ridwan. 2014. Two artificial diets formulation for Troides helena Linne larvae (Lepidoptera: Paillionidae) in Bantimurung-Bulusaraung 
National Park, South Sulawesi. Intern. J. Sci Tech. Res. 3(7): 170-173.

Noda, T. and S. Kamano. 2002. Artificial rearing of Nezara viridula (L.) and N. Antennata Scott (Heteroptera: Pentatomidae) with semi-solid meredic diets. Appl. Entomol. Zool. 37(1): 43-50.

Parera, M. T. M. D. R., N. Senanayake and A. G. P K. Premachandra. 2015. Formulation of low cost artificial diet for rearing diamondback moth (Plutella xylostella, L.). Srilanka J. Food and Agric.1(1): 25-33.

Russell, W. C. and K. S. Pelz-Stelinski. 2015. Development of an artificial diet and feeding system for juvenile stages of the Asian citrus psyllid, Diaphorina citri. Entomologia Experimentalis et Applicata 154: 171176.

Salvador, C. M., A. L. Boica, Jr., M. C.N. de Oliveira, J. P. Da Graca, D. M. Da Silva and C. B. HoffmannCampo. 2010. Do different casein concentration increase the adverse effect of rutin on the biology of Anticarsia gemmatalis Hubner (Lepidoptera: Noctuidae)?. Neotropical Entomo. 39(5): 774-783.

Sorour M. A., O. Khamiss, A. S. A. El Wahab, M. A. K. ElSheikh and S. Abul-Ela. 2011. An Economically Modified Semi-synthetic Diet for Mass Rearing the Egyptian Cotton Leaf Worm Spodoptera littolaris. Acad. J. Entomol. 4(3): 118-123.

Sujatha, S. and B. Joseph. 2011. Development of tapioka oligidic diet and its effects of mass rearing performance (biology) on lepidoptera pest of Spodoptera litura (Fab.) (Lepidoptera: Noctuidae). J. Entomology: 1-6.

Susrama, I G. K. 2017. Kebutuhan nutrisi dan substansi dalam pakan buatan serangga (Artikel Ulasan). $J$. Agroekoteknologi Tropika 6(3): 310-318.

Wang, P., P. F. Lu, X. L. Zheng, L. Z. Chen, C. L. Lei and X. P. Wang. 2013. New artificial diet for continous rearing of the bean pod borer Maruca vitrata. $J$. Insect Sci. 13(121): 1-11. 